\title{
Phytoplankton lysis predicts dissolved organic carbon release in marine plankton communities
}

\author{
S. Agustí ${ }^{1,2}$ and C. M. Duarte ${ }^{1,2}$ \\ ${ }^{1}$ Department of Global Change Research, IMEDEA (CSIC-UIB), Instituto Mediterráneo de Estudios Avanzados, \\ Miquel Marqués 21, 07190 Esporles, Spain \\ ${ }^{2}$ The UWA Oceans Institute and School of Plant Biology, University of Western Australia, 35 Stirling Highway, \\ Crawley 6009, Australia
}

Correspondence to: S. Agustí (sagusti@imedea.uib-csic.es)

Received: 19 October 2011 - Published in Biogeosciences Discuss.: 7 December 2011

Revised: 17 January 2013 - Accepted: 23 January 2013 - Published: 1 March 2013

\begin{abstract}
The relationship between the percent extracellular carbon release (PER) and the specific lysis rates of phytoplankton was examined across a range of communities spanning from highly oligotrophic ones in the subtropical Atlantic Ocean to productive ones in the N. African upwelling and the Southern Ocean. Communities in oligotrophic waters supported high phytoplankton cell lysis rates and low particulate primary production rates but high dissolved primary production and PER. The percent extracellular carbon released increased with increasing lysis rates to reach an asymptote at about $80 \%$ PER with specific lysis rates $>1.5 \mathrm{~d}^{-1}$, observed in the most oligotrophic conditions tested. These results confirm that high phytoplankton mortality in the oligotrophic ocean leads to high PER, accounting for the large fraction of the photosynthetic carbon channelled through bacteria characteristic of oligotrophic marine communities.
\end{abstract}

\section{Introduction}

Reconciling high bacteria carbon use with estimates of primary production and carbon flow from phytoplankton has remained a challenge for over two decades, particularly for the oligotrophic ocean (Williams, 1984; del Giorgio et al., 1997; del Giorgio and Duarte, 2002). A high flux of phytoplankton carbon through bacteria in oligotrophic waters requires the release of much of phytoplankton production in dissolved form, as supported by reports of high release of dissolved organic carbon in the oligotrophic ocean (Karl et al., 1998;
Teira et al., 2001; Morán et al., 2002). A number of factors contribute to DOC release from phytoplankton (Myklestad, 2000), including excretion of DOC (Sharp, 1977), sloppy feeding by zooplankton (Møller et al., 2003), and cell lysis due to viral infections (Wilhelm and Suttle, 1999) or senescence (Myklestad, 2000).

Reports of high dissolved organic carbon release by phytoplankton in the 1980 s raised concerns as to the possible role of experimental artefacts in accounting for this observation, as healthy phytoplankton cells, assumed to prevail in natural communities, could not possibly release in dissolved form such high fractions of their primary production (Sharp, 1977). Yet, progress in assessing the status of phytoplankton cells using vital stains has demonstrated a prevalence of dead and decaying cells (e.g. Agustí and Sánchez, 2002; Alonso-Laita and Agustí, 2006; Hayakawa et al., 2008), conducive to high phytoplankton cell lysis and mortality rates in oligotrophic waters (Agustí et al., 1998, 2001; Agustí, 2004; Hayakawa et al., 2008). In contrast, phytoplankton communities in productive ocean regions are characterized by higher cell viability (Alonso-Laita and Agustí, 2006). Hence, high phytoplankton cell mortality and subsequent lysis could account for the high relative dissolved primary production often observed in the oligotrophic ocean compared to more productive waters (Teira et al., 2001; Morán et al., 2002), as suggested by Agustí et al. (1998, 2001). However, the relationship between dissolved primary production and cell lysis rates has not yet been tested.

Here we examine the relationship between the percent extracellular release of dissolved organic carbon and specific 
phytoplankton cell lysis rates. We examined this relationship across a range of communities spanning from highly oligotrophic ones in the subtropical Atlantic Ocean to productive ones in the NW African upwelling region and the Southern Ocean.

\section{Methods}

Concurrent measurements of dissolved and particulate primary production and cell lysis rates were carried out during two oceanographic cruises on board R/V Hespérides: (1) the COCA-2 cruise (19 May-14 June 2003), occupying the transition zone between the northeast coastal upwelling of Africa and the oceanic waters of the North Atlantic at $26^{\circ} \mathrm{W}$, where measurements were conducted in a total of 8 stations spanning from highly oligotrophic waters in the subtropical Atlantic gyre to highly productive ones at the $\mathrm{N}$. African coastal upwelling; and (2) the ICEPOS 2005 cruise conducted on board R/V Hespérides (2 to 21 February 2006), where measurements were conducted in waters encompassing moderately to highly productive waters along the Antarctic Peninsula.

The measurements were conducted using surface $(5 \mathrm{~m}$ depth) communities, sampled using $12 \mathrm{~L}$ GO-FLO-like Niskin bottles (i.e. with external closing mechanisms) attached to a Rosette sampling system. Dissolved and particulate production were quantified using ${ }^{14} \mathrm{C}$ additions (Steeman-Nielsen, 1952). Two dark and two light $125 \mathrm{~mL}$ polycarbonate bottles were filled and inoculated with different amounts of $\mathrm{NaH}^{14} \mathrm{CO}_{3}$ (range 10 to $80 \mu \mathrm{Ci}$ ) depending on the productivity of the waters. The bottles were incubated for $6 \mathrm{~h}$ on deck at in situ temperature in a controlled-temperature bath and using neutral screens to adjust for in situ irradiance.

After the incubation period, sample bottles were placed in dark plastic bags until filtration. Two aliquots of $5 \mathrm{~mL}$ were sampled and placed in $20 \mathrm{~mL}$ scintillation vials for determination of total labelled organic carbon (TOC). Liquid samples (TOC) were acidified with $100 \mu \mathrm{L}$ of $\mathrm{HCl} 10 \%$ and were shaken overnight. Then $20 \mathrm{~mL}$ of Packard Ultima Gold XR scintillation cocktail were added. The remaining volume of the original sample was filtered through $0.22 \mu \mathrm{m}$ cellulose membrane filters for determination of the total labelled organic carbon (POC $>0.22 \mu \mathrm{m}$ ) retained in the filters, as use of glass fibre filters has been reported to overestimate particulate primary production (Karl et al., 1998). Ideally, this fraction is expected to include all photosynthetically produced particulate organic carbon contained in algal biomass plus the bacterial POC (particle organic carbon) resulting from bacterial uptake of DOC released by algae as well as any bacterial biomass ingested by micrograzers. Filters were fumed with concentrated $\mathrm{HCl}(37 \%)$ to remove inorganic carbon for a minimum of $12 \mathrm{~h}$ before addition of $10 \mathrm{~mL}$ of Packard Ultima Gold XR scintillation cocktail. Radioactivity was mea- sured after $24 \mathrm{~h}$ on board in a EG\&G/WALLAC 1414-001 winspectral liquid scintillation counter.

Samples of $200 \mathrm{~mL}$ were filtered through Whatman GF/F filters to estimate total chlorophyll $a$ concentration ( $\mathrm{chl} a$ ). Chl $a$ was measured fluorometrically using a Turner Designs fluorometer, in $90 \%$ acetone extracts of filters preserved frozen following Parsons et al. (1984).

Specific phytoplankton cell lysis rates were estimated from the quantification of the dissolved esterase activity (DEA), measured in triplicate using the spectrofluorometric technique described by van Boekel et al. (1992) as modified by Agustí et al. (1998) and Agustí and Duarte (2000). In short, $5 \mathrm{~mL}$ water samples were filtered through a $0.45 \mu \mathrm{m}$ Millipore Millex filter, and $50 \mu \mathrm{L}$ of Ethylenediaminetetraacetic acid (EDTA) and $50 \mu \mathrm{L}$ of fluorescein diacetate (FDA, Sigma Chemical) were added to the samples (to a final concentration of 0.02 and $0.2 \mathrm{mM}$, respectively) and mixed in a vortex mixer. After incubating the samples for $1 \mathrm{~h}$ at $20^{\circ} \mathrm{C}$, the fluorescence emission was measured immediately in a Shimadzu RF-5000 spectrofluorometer at 451 and $510 \mathrm{~nm}$ excitation and emission (10 nm bandwidth) wavelengths, respectively. Fluorescein production (nmol fluorescein liter ${ }^{-1} \mathrm{~h}^{-1}$ ) was calculated using a standard calibration curve obtained by measuring the fluorescence of a range of fluorescein (Sigma Chemical) solutions (3-2000 nmol fluorescein liter ${ }^{-1}$ of filtered seawater). The initial particulate esterase activity (PEA) was calculated from the measured chl $a$ concentration using PEA to chl $a$ ratios derived from phytoplankton cultures (Agustí et al., 1998; Agustí and Duarte, 2002). A ratio of PEA to chl $a$ of $224 \pm 83$ (Mean $\pm \mathrm{SE}$ ) nmol Fluoresceine $\mathrm{h}^{-1} \mathrm{mg}^{-1} \mathrm{chl} a$ was used for the more productive communities in the subtropical NE Atlantic (stations sampled in the Canary Current and the upwelling regions) and the Bransfield Strait (Agustí and Duarte, 2002). A ratio of PEA/chl $a$ ratio of $377 \pm 101$ nmol fluoresceine $\mathrm{h}^{-1} \mathrm{mg}^{-1} \mathrm{chl} a$, derived from the PEA of picophytoplankton cultures (Prochlorococcus marina, Synechococcus sp. (strain \#1), Synechococcus sp. (strain \#2), and, Chlorella marina), was used for the communities in the most oligotrophic area (subtropical gyre, Table 1).

The production of DEA, needed for the calculation of lysis rates, was derived from the rate of DEA decrease with time measured in experiments conducted on board parallel to sampling in a total of 10 experiments.

The mean $( \pm \mathrm{SE})$ DEA decay rate obtained was $0.042 \pm 0.0084 \mathrm{~h}^{-1}$. The specific phytoplankton cell lysis rate $\left(\mu_{\mathrm{L}}, \mathrm{d}^{-1}\right)$ was calculated from the decrease in PEA over time $(t=1 \mathrm{~d})$ due to the production of dissolved EA during cell lysis.

$\mu_{\mathrm{L}}\left(\mathrm{d}^{-1}\right)=\frac{\ln \left(\frac{\mathrm{PEA}_{t}}{\mathrm{PEA}_{0}}\right)}{t}$,

where PEA represents the initial particulate esterase activity, estimated as described above, and $\mathrm{PEA}_{t}$ is the particulate 
Table 1. Chl $a$, particulate and dissolved primary production (PP), specific cell lysis rate (day ${ }^{-1}$ ), and percent extracellular carbon release (PER, \%) in the communities tested in the NE subtropical Atlantic and waters off the Antarctic Peninsula.

\begin{tabular}{llrrrrr}
\hline Region & Station & $\begin{array}{r}\mathrm{chl} a \\
\left(\mu \mathrm{gchl} a \mathrm{~L}^{-1}\right)\end{array}$ & $\begin{array}{r}\text { Particulate PP } \\
\left(\mu \mathrm{g} \mathrm{CL}^{-1} \mathrm{~h}^{-1}\right)\end{array}$ & $\begin{array}{r}\text { Dissolved PP } \\
\left(\mu \mathrm{g} \mathrm{CL}^{-1} \mathrm{~h}^{-1}\right)\end{array}$ & $\begin{array}{r}\text { Specific lysis } \\
\left(\mathrm{d}^{-1}\right)\end{array}$ & $\begin{array}{r}\text { PER } \\
(\%)\end{array}$ \\
\hline \multirow{5}{*}{ NE Subtropical Atlantic } & Canary Current 1 & 0.45 & 3.00 & 2.18 & 0.102 & 42.1 \\
& Canary Current 2 & 0.16 & 2.16 & 2.16 & 0.349 & 49.9 \\
& Subtropical Gyre 1 & 0.10 & 1.89 & 3.74 & 0.474 & 66.4 \\
& Subtropical Gyre 2 & 0.04 & 0.72 & 4.36 & 0.602 & 85.8 \\
& Subtropical Gyre 3 & 0.15 & 1.83 & 3.28 & 0.310 & 64.2 \\
& Subtropical Gyre 4 & 0.15 & 0.62 & 1.47 & 1.093 & 70.3 \\
& Upwelling 1 & 2.73 & 21.25 & 0.06 & 0.018 & 0.3 \\
& Upwelling 2 & 4.27 & 32.31 & 0.32 & 0.003 & 1.0 \\
& Geometric Mean & 0.31 & 3.02 & 1.27 & 0.145 & 18.6 \\
\hline \multirow{5}{*}{ Antarctic Peninsula } & Bransfield Strait 1 & 1.88 & 4.58 & 2.16 & 0.035 & 32.1 \\
& Bransfield Strait 2 & 2.09 & 6.18 & 0.72 & 0.077 & 10.4 \\
& Bransfield Strait 3 & 2.19 & 4.98 & 1.01 & 0.090 & 16.9 \\
& Bransfield Strait 4 & 2.78 & 10.44 & 0.41 & 0.049 & 3.8 \\
& Geometric Mean & 2.21 & 6.19 & 0.90 & 0.059 & 12.1 \\
\hline
\end{tabular}

esterase activity expected after a time interval $t$ in days. PEA was calculated as $\mathrm{PEA}_{0}$ minus the production of DEA, $\mathrm{DEA}_{\text {(Prod) }}$. The production of DEA was derived by combining the measured DEA activity with estimates of the rate of loss of the activity of the enzyme calculated in experiments conducted at each station. Because esterases are intracellular enzymes, their release to the medium involves a severe change in ambient conditions (e.g. $\mathrm{pH}$ and exposure to oxidizing agents), which explains the general loss of activity of intracellular enzymes when released to seawater (Wetzel, 1991). The experiments consisted of adding commercial esterases (porcine liver esterases, Sigma E-3128) to water samples maintained at in situ temperature. The time series of loss of EA was followed by sampling at increasing time intervals $(0,1,3,6,12$, and $24 \mathrm{~h})$ to obtain an exponential decay curve. The exponential rate of DEA decay was calculated from the changes in DEA during time ( $t$, days) by fitting an exponential decay equation. The half-life of EA, $T \frac{1}{2}$ (d), was then calculated as $0.693 / r$, where $r$ was the experimentally determined exponential decay rate for EA $\left(\mathrm{d}^{-1}\right)$. Under steady state, the production of DEA from PEA through cell lysis (DEA $_{(\text {Prod) }}$ ) should equal $\frac{1}{2}$ DEA at $T \frac{1}{2}$ (d), (Agustí et al., 1998).

The estimates of lysis rates presented include uncertainty derived from variability in PEA/chl $a$ for the individual communities sampled and from contributions of heterotrophs to EA activity. These are, however, likely to be small sources of uncertainty, as Agustí and Duarte (2002) estimated variability in PEA/chl $a$ across communities ranging from diatomdominated to picoplankton-dominated to add $16 \%$ uncertainty to lysis rate estimates, and Agustí et al. (1998) calculated heterotroph release of DEA to contribute only $5 \%$ of the dissolved esterase activity.

\section{Results}

The communities investigated ranged broadly in biomass, as indicated by chl $a$, particulate and dissolved primary production rates and percent extracellular release (Table 1). The communities in the subtropical NE Atlantic were more variable than those off the Antarctic Peninsula, as the region sampled in the subtropical NE Atlantic encompasses a gradient from unproductive communities in the oligotrophic gyre to highly productive communities in the upwelling region off the African coast.

Calculated specific cell lysis rates ranged greatly among communities ( 0.003 to $1.09 \mathrm{day}^{-1}$, Table 1$)$ and tended to be highest in communities in the most oligotrophic waters sampled. Specific cell lysis rates were far more variable in the subtropical NE Atlantic than in the communities sampled off the Antarctic Peninsula, which showed relatively low lysis rates (Table 1). Specific lysis rates were high in communities sampled in the oligotrophic NE subtropical Atlantic gyre and were very low in the waters affected by the upwelling off the NW African coast.

Particulate primary production and lysis rates were negatively correlated (Fig. 1), and the percent extracellular organic carbon release (PER) in the experiments increased strongly with increasing specific cell lysis rates (Fig. 2). The relationship conformed to a Michealis-Menten equation of the following form:

$$
\begin{aligned}
& \text { PER }(\%)=\frac{100 \mu_{\mathrm{L}}}{0.275+\mu_{\mathrm{L}}} \\
& \left(R^{2}=0.83, P<0.001\right),
\end{aligned}
$$




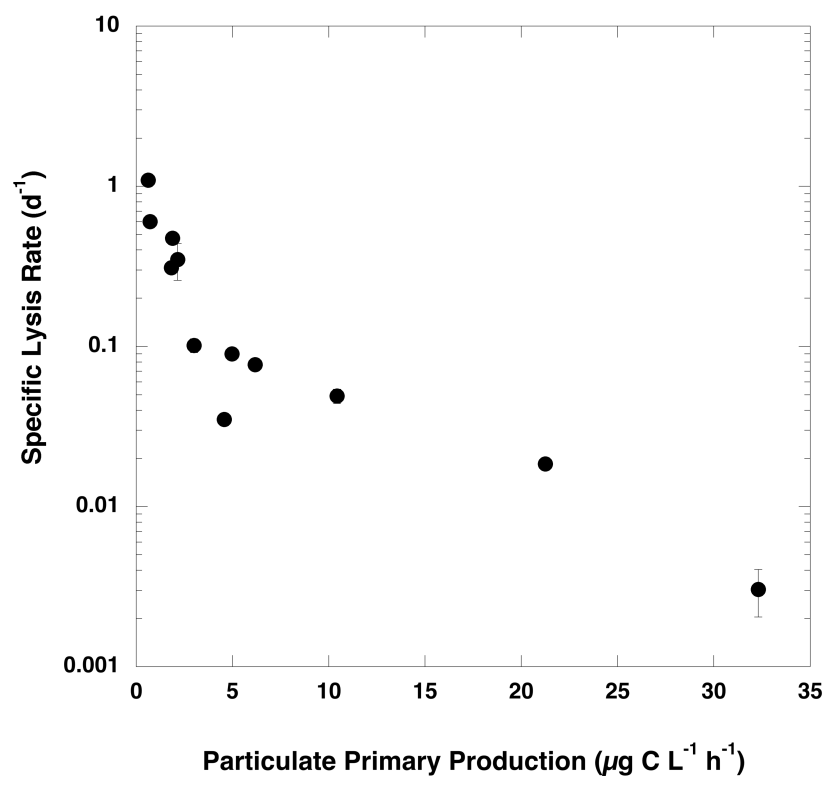

Fig. 1. The relationship between phytoplankton lysis rates and particulate primary production in the communities investigated. Error bars represent $\pm 1 \mathrm{SE}$.

where $\mu_{\mathrm{L}}$ is the specific lysis rate $\left(\mathrm{d}^{-1}\right)$. The relationship indicated that PER reaches an asymptotic value at about $80 \%$ with specific lysis rates in excess of 1.0 day $^{-1}$ (Fig. 2).

\section{Discussion}

Evidence that unproductive plankton communities release a high fraction of the primary production as dissolved organic carbon abounds (Karl et al., 1998; Teira et al., 2001; Morán et al., 2002). Indeed, the release of a high fraction of the phytoplankton primary production as dissolved organic carbon in the oligotrophic ocean plays a pivotal role in explaining the high bacterial carbon use relative to particulate primary production in oligotrophic waters (del Giorgio et al., 1997) and, more broadly, the tight coupling between the microbial food web and primary producers characteristic of the oligotrophic ocean (Azam et al., 1983). Phytoplankton release of dissolved organic carbon results from a number of processes, including exudation of organic carbon (Sharp, 1977), sloppy feeding by zooplankton (Møller et al., 2003), and cell lysis due to viral infections (Wilhelm and Suttle, 1999) or senescence (Myklestad, 2000).

The results presented here indicate that the partitioning of photosynthetic carbon between dissolved and particulate components depends closely upon specific phytoplankton lysis rates. The high average dissolved primary production rates in unproductive communities $(>50 \%$ of total primary production, Karl et al., 1998; Teira et al., 2001; Morán et al., 2002) cannot be explained by excretion by healthy cells, as argued in the past (Sharp, 1977). Sharp (1977) showed that healthy cells do not excrete significant amounts of DOC,

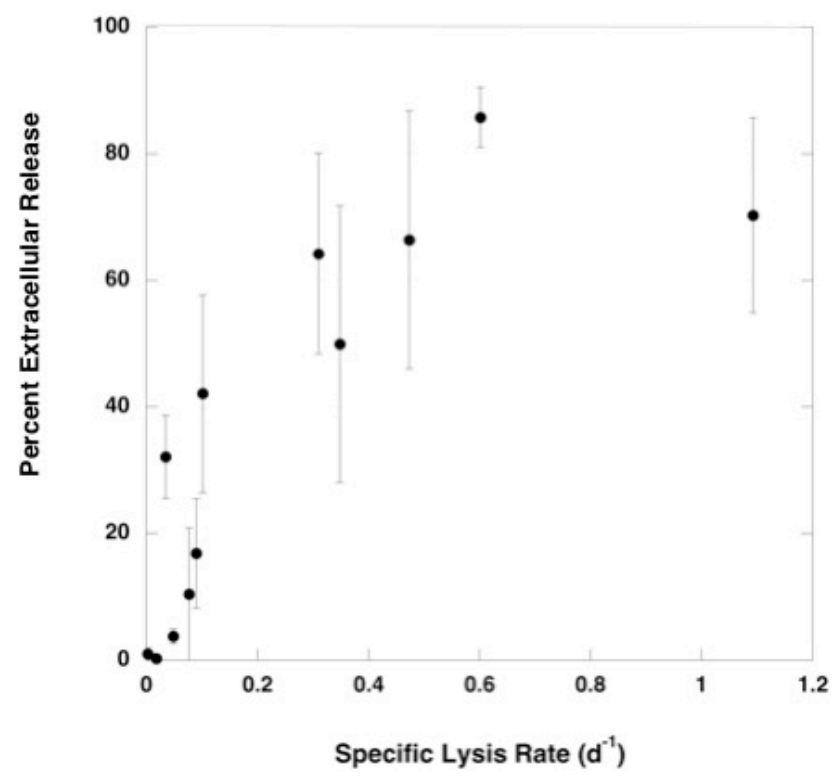

Fig. 2. The relationship between the mean $( \pm S E)$ percent extracellular organic carbon release (PER) and the mean $( \pm \mathrm{SE})$ specific phytoplankton lysis rates in the communities investigated.

consistent with very low $(<10 \%)$, extracellular release of organic carbon in the more productive communities investigated here but concluded, following Duursma (1963), that dead or decaying phytoplankton cells must be responsible for high DOC release rates in the oligotrophic ocean. The conclusions could not be tested, since techniques to assess cell viability and lysis rates were not then available.

Assessments of cell status in oligotrophic waters have provided evidence that a large proportion of phytoplankton cells are dead or compromised (Agustí and Sánchez, 2002; Agustí, 2004; Alonso-Laita and Agustí, 2006; Hayakawa et al., 2008), supporting high mortality and lysis rates in oligotrophic waters (Agustí et al., 1998, 2001; Llabrés et al., 2011). The distributions of dead or compromised cells in the communities differ across species. For instance Agustí (2004) reported a niche segregation of Synechococcus and Prochlorococcus, based on the distribution of dead cells, with the former performing better in warm surface waters and the latter in deeper, low light and colder waters. Moreover, the turnover of dead and compromised cells in the community is relatively fast (Marbá et al., 2007). Considerable research has also focused on the drivers of mortality, identifying a broad range of stresses causing mortality, particularly of the apparently more vulnerable picoautotrophs, such as UVB radiation (Llabrés and Agustí, 2006; Agustí and Llabrés, 2007; Llabrés et al., 2010), hydroxyl radicals (Llabrés and Agustí, 2012), viral infections (Suttle et al., 1990), accumulated damages and stresses (Llabrés and Agustí, 2011), nutrient limitation (Berges and Falkowski, 1998), persistent organic pollutants (Echeveste et al., 2010), and even bursts of gamma rays from extrasolar events (Peñate et al., 2010). There has also 
been considerable progress in our understanding in the cellular processes conducive to lysis rates (Biddle and Falkowski, 2004).

Cell lysis is, therefore, a major loss process, particularly in the oligotrophic ocean (Agustí and Sánchez, 2002; Agustí, 2004; Alonso-Laita and Agustí, 2006), with rates comparable to grazing losses (Hayakawa et al., 2008). The presence of stable autotroph populations in the oligotrophic ocean implies, therefore, that these populations turn over rapidly, consistent with high gross growth rates reported in the oligotrophic ocean (Vaulot et al., 1995; Vaulot and Marie, 1999).

Observation of high cell lysis rates and a high proportion of dead or compromised autotrophic cells in oligotrophic waters led to the formulation of the hypothesis that phytoplankton cell lysis must be a significant vector for DOC production in the oligotrophic ocean (Agustí et al., 1998, 2001), driving a significant flux of DOC to the microbial food web (Agustí et al., 2001). The relationship between cell lysis rates and dissolved primary production and PER presented here provides strong evidence that the high flux of DOC in unproductive communities, up to $80 \%$ of total primary production, is largely driven by cell lysis. Accordingly, particulate primary production declines sharply with lysis rates, as an increasing fraction of primary production is released in dissolved form.

The strong relationship between independently assessed specific phytoplankton cell lysis rates and PER demonstrated here provides, $30 \mathrm{yr}$ later, the answer to the rhetoric question, "Do healthy cells do it?" (Sharp, 1977). The results presented show that the high DOC release rates by phytoplankton in the oligotrophic ocean are not supported by healthy cells but, rather, by dying ones, as suspected long ago (Duursma, 1963). Evidence for high lysis rates (Agustí et al., 1998, 2001; Hayakawa et al., 2008) and a high percentage of dying or compromised cells (Agustí, 2004; Alonso-Laita and Agustí, 2006; Lasternas et al., 2010; Llabrés and Agustí, 2011; Hayakawa et al., 2008) as characteristic properties of phytoplankton communities in the oligotrophic ocean is accumulating in parallel to an increased understanding of the multiple cellular and molecular mechanisms (Bidle et al., 2004) and environmental drivers (Llabrés and Agustí, 2006; Echeveste et al., 2010) responsible for these high mortality rates. Phytoplankton mortality is, therefore, a fundamental process shaping carbon flow in the oligotrophic ocean.

Acknowledgements. This is a contribution to the "Malaspina 2010" CONSOLIDER project funded by the Spanish Ministry of Science and Innovation (CSD2008-00077). We thank P. J. leB. Williams and an anonymous reviewer for constructive comments. We thank the crew, captains and technicians of R/V Hespérides and Pelagia for assistance during this study. We thank P. Alonso-Laita for technical help and G. Herndl for the invitation to participate in the BADE cruises.

Edited by: C. Robinson

\section{References}

Agustí, S.: Viability and niche segregation of Prochlorococcus and Synechococcus cells across the central Atlantic Ocean, Aquat. Microb. Ecol., 36, 53-59, 2004.

Agustí, S. and Duarte, C. M.: Strong seasonality in phytoplankton cell lysis in the NW Mediterranean littoral, Limnol. Oceanogr., 45, 940-947, 2000.

Agustí, S. and Sánchez, M. C.: Cell viability in natural phytoplankton communities quantified by a membrane permeability probe, Limnol. Oceanogr., 47, 818-828, 2002.

Agustí, S., Satta, M. P., Mura, M. P., and Benavent, E.: Dissolved esterase activity as a tracer of phytoplankton lysis: Evidence of high phytoplankton lysis rate in the northwestern Mediterranean, Limnol. Oceanogr., 43, 1836-1849, 1998.

Agustí, S., Duarte, C. M., Vaque, D., Hein, M. J., Gasol, M., and Vidal, M.: Food-web structure and elemental $(\mathrm{C}, \mathrm{N}$ and $\mathrm{P})$ fluxes in the eastern tropical North Atlantic, Deep-Sea Res. II, 48, 22952321, 2001.

Alonso-Laita, P. and Agustí, S.: Contrasting patterns of phytoplankton viability in the subtropical NE Atlantic Ocean, Aquat. Microb. Ecol., 43, 67-78, 2006.

Azam, F. and Malfatti, F.: Microbial structuring of marine ecosystems, Nat. Rev. Microbiol., 5, 782-791, 1997.

Azam, F., Fenchel, T., Field, J. G., Gray, J. S., Meyer-Reil, L. A., and Thingstad, F.: The ecological role of water-column microbes in the sea, Mar. Ecol. Prog. Ser., 10, 257-263, 1983.

Berges, J. A. and Falkowski, P. G.: Physiological stress and cell death in marine phytoplankton: Induction of proteases in response to nitrogen or light limitation, Limnol. Oceanogr., 43, 129-135, 1998.

Bidle, K. D. and Falkowski, P. G.: Cell death in planktonic, photosynthetic microorganisms, Nat. Rev. Microbiol., 2, 643-655, 2004.

del Giorgio, P. A. and Duarte, C. M: Respiration in the open ocean, Nature, 420, 379-384, 2002.

del Giorgio, P. A, Cole, J. J., and Cimbleris, A.: Respiration rates in bacteria exceed plankton production in unproductive aquatic systems, Nature, 385, 148-151, 1997.

Duursma, E. K.: The production of dissolved organic matter in the sea, as related to the primary gross production of organic matter, Neth. J. Sea Res., 2, 85-94, 1963.

Echeveste, P. J., Dachs, N. Berrojaldiz, and Agustí, S.: Decrease in the abundance and viability of oceanic phytoplankton due to trace levels of complex mixtures of organic pollutants, Chemosphere, 81, 161-168, 2010.

Hayakawa, M., Suzuki, K., Saito, H., Takahashi, K., and Ito, S.-I.: Differences in cell viabilities of phytoplankton between spring and late summer in the northwest Pacific Ocean, J. Exp. Mar. Biol. Ecol., 360, 63-70, 2008.

Karl, D. M., Hebel, D. V., Björkman, K., and Letelier, R. M.: The role of dissolved organic matter release in the productivity of the oligotrophic North Pacific Ocean, Limnol. Oceanogr., 43, 12701286, 1998.

Lasternas, S., Agustí, S., and Duarte, C. M.: Phyto- and bacterioplankton abundance and viability and their relationship with phosphorus across the Mediterranean Sea, Aquat. Microb. Ecol., 60, 175-191, 2010.

Llabrés, M. M. and Agustí, S.: Picophytoplankton cell death induced by UV radiation: evidence for oceanic Atlantic commu- 
nities, Limnol. Oceanogr., 51, 21-29, 2006.

Llabrés, M., Alonso-Laita, P, Herndl, G. J., and Agustí, S.: Synechococcus and Prochlorococcus cell death induced by UV radiation and the penetration of lethal UVR in the Mediterranean Sea, Mar. Ecol. Progr. Ser., 399, 27-37, 2010.

Llabrés, M., Agustí, S., and Herndl, G. J.: Diel in situ picophytoplankton cell death cycle coupled with cell division, J. Phycol., 47, 1247-1257, 2011.

Llabrés, M., Dachs, J., and Agustí, S.: Transference of atmospheric hydroxyl radical to the ocean surface induces high phytoplankton cell death, Photochem. Photobiol., 88, 1473-1479, 2012.

Marbá, N., Duarte, C. M., and Agustí, S.: Allometric scaling of plant mortality rate, P. Natl. Acad. Sci. USA, 104, 15777-15780, 2007.

Møller, E. F., Thor, P., and Nielsen, T. G.: Production of DOC by Calanus finmarchicus, C. glacialis and C. hyperboreus through sloppy feeding and leakage from fecal pellets, Mar. Ecol. Prog. Ser., 262, 185-191, 2003.

Moran, X. A. G., Estrada, M., Gasol, J. M., and Pedros-Alio, C.: Dissolved primary production and the strength of phytoplanktonbacterioplankton coupling in contrasting marine regions, Microb. Ecol., 44, 217-223, 2002.

Myklestad, S. M.: Dissolved organic carbon from phytoplankton, in: Mar. Chem., edited by: Wangersky, P. J., Springer, Berlin, Germany, 111-148, 2000

Parsons, T. R., Maita, Y., and Lalli., C. M.: A manual of chemical and biological methods for seawater analysis, Pergamon Press, 1984.

Peñate L., Martín, O., Cárdenas, R., and Agustí, S.: Short-term effects of Gamma Ray Bursts on oceanic photosynthesis, Astrophys. Space Sci., 330, 211-217, doi:10.1007/s10509-010-04507,2010 .
Sharp, J. H.: Excretion of organic matter by marine phytoplankton: Do healthy cells do it?, Limnol. Oceanogr., 22, 381-399, 1977.

Steeman-Nielsen, E.: The use of radio-active carbon (C14) for measuring organic production in the sea, J. Cons. Int. Explor. Mer, 18, 117-140, 1952.

Suttle, C. A., Chan, A. M., and Cottrell, M. T.: Infection of phytoplankton by viruses and reduction of primary productivity, Nature, 347, 467-469, 1990.

Teira, E., Pazó, M. J., Serret, P., and Fernández, E.: Dissolved organic carbon production by microbial communities in the Atlantic Ocean, Limnol. Oceanogr., 46, 1370-1377, 2001.

van Boekel, W. H. M., Hansen, F. C., Riegman, R., and Back, R. P. M.: Lysis-induced decline of a Phaeocystis spring bloom and coupling with the microbial foodweb, Mar. Ecol. Progr. Ser., 81, 269-276, 1992.

Vaulot, D. and Marie, D.: Diel Variability of photosynthetic picoplankton in the equatorial Pacific, J. Geophys. Res., 104, 3297-310, 1999.

Vaulot, D., Marie, D., Olson, R. J., and Chisholm, S. W.: Growth of Prochlorococcus, a photosynthetic prokaryote, in the equatorial Pacific Ocean, Science, 268, 1480-1482, 1995.

Wetzel, R. G.: Extracellular enzymatic interactions: Storage, redistribution and interspecific communication, in: Microbial enzymes in aquatic environments, edited by: Chróst, R. J., Brock/Springer, Series in Contemporary Bioscience, 6-28, 1991.

Wilhelm, S. W. and Suttle, C. A., Viruses and Nutrient Cycles in the Sea, BioScience, 49, 781-788, 1999.

Williams, P. J. leB.: Bacterial production in the marine food chain: the emperor's new suit of clothes?, in: Heterotrophic activity in the Sea, edited by: Hoppe, H. G., 271-299, NATO, 1984. 